\title{
Connecting knowledge with action through coproductive capacities: adaptive governance and connectivity conservation
}

\author{
Carina A. Wyborn $^{1}$
}

\begin{abstract}
Effective adaptive governance will emerge from strong relationships between science, governance, and practice. However, these relationships receive scant critical attention among adaptive governance scholarship. To address this lacuna, Jasanoff's "idiom of coproduction" provides a lens to view the dialectical relationships between science and society. This view sees science and governance as coevolving through iterative relationships between the material, cognitive, social, and normative dimensions of a problem. This coevolution is precisely the aspiration of adaptive governance; however, the abstract notion of coproduction must be grounded to provide practical guidance for groups aspiring to "govern adaptively." I have drawn on three concepts, namely coproduction, bridging/ boundary organizations, and adaptive capacity, to present a conceptual framework of "coproductive capacities." Coproductive capacities are the material, cognitive, social, and normative capacities that enable groups of actors to connect knowledge with action in a cross-scale governance context. This framework was applied to two cases of connectivity conservation. Inspired by the science of conservation biology, connectivity conservation promotes collaborative, cross-scale governance to conserve biodiversity at a landscape scale. This tight coupling of science and governance in a cross-scale context makes connectivity conservation a classic case of both coproduction and adaptive governance. However, the inability of the initiatives in the cases examined to turn their visions into action highlights a critical absence of key capacities. In particular, challenges faced in connecting knowledge with action at various scales points to the importance of building relationships between actors across scales. The structures and mechanisms of governance have dominated adaptive governance scholarship, yet coproductive capacity and adaptive governance emerge from the relationships between actors seeking to connect knowledge with action. Building capacity to negotiate these relationships is a more fruitful focus for adaptive governance than design principles and diagnostics.
\end{abstract}

Key Words: adaptive capacity; adaptive governance; boundary organizations; bridging organizations; connectivity conservation; coproduction; coproductive capacities

\section{INTRODUCTION}

Adaptive governance links actors across scales to address resource management challenges bridging social and ecological systems (Folke et al. 2005). Complexity and uncertainty characterize arenas of adaptive governance because social-ecological systems are subject to constant change. Consequently, flexibility and adaptability remain key aspirations for environmental governance (Plummer and Armitage 2010). To be adaptive within a dynamic context requires strong connections between science and governance, without which the capacity to act may be constrained by decision-making processes unable to respond to new insights or conditions. Although adaptive governance requires strong connections between science and governance, these domains are often separated in theory and practice. Theoretically, we understand the processes of science and governance with different concepts; practically, the mechanisms of governance are rarely understood in relation to the scientific understandings of a problem or context. In contrast, Jasanoff's idiom of coproduction proposes that science and governance emerge from coevolutionary interactions between material, cognitive, social, and normative domains (2004a). Accounts of coproduction illustrate how knowledge production is deeply embedded within social and institutional contexts and how, in turn, that context shapes new knowledge production (Jasanoff 2004b). This tight coupling of knowledge making and decision making is precisely the goal of adaptive governance: When knowledge of a system changes, decision making responds.

Coproductive capacity focuses on the capacities and relationships that enable actors to govern adaptively (Van Kerkhoff and Lebel
2015). I draw on three concepts, coproduction, bridging/ boundary organizations, and adaptive capacity, to propose that coproductive capacity emerges from strong relationships between knowledge and action. Governance refers to the processes groups of actors adopt to negotiate decisions and determine a path of action (Lemos and Agrawal 2006). Capacity is the realized ability of actors to identify and solve problems (Virji et al. 2012), whereas adaptive capacity concerns the ability of actors to withstand and respond to change (Walker and Salt 2006). Boundary/bridging organizations operate to build connections between actors in a governance network (Sternlieb et al. 2013). These concepts underpin a conceptual framework of coproductive capacities theorized to support governance that connects knowledge with action. This framework is applied to two empirical cases of connectivity conservation, one in Australia and one in North America.

Connectivity conservation seeks to address landscape-scale ecological and institutional fragmentation through collaborative conservation (Worboys et al. 2010, Wyborn 2011). Drawing heavily on adaptive governance scholarship, proponents aspire to create locally responsive governance while maintaining coherence across vertical, i.e., jurisdictional, and horizontal, i.e., land tenure, scales (see Lockwood 2010). Connectivity conservation attempts to realign governance based on scientific and normative propositions about the inherent value of large intact landscapes (Wyborn 2013). This blurring of science and governance makes connectivity conservation a classic case of coproduction and an ideal empirical setting to explore the ideas of coproductive capacities. In both cases, the initiatives draw on scientific concepts 
to justify their approach to governance, replicating the tight coupling of science and governance identified as coproduction. However, challenges faced turning their visions into action through cross-scale governance highlight an absence of critical relationships between knowledge and action.

Coproductive capacity highlights the material, cognitive, social, and normative resources required to produce effective relationships between science and governance (Van Kerkhoff and Lebel 2015). The adaptive governance literature points to a variety of mechanisms, collaboration, polycentric governance, and social learning, to build cross-scale governance (Folke et al. 2005, Lebel et al. 2006). Moving beyond these mechanisms, I focus on the capacities that build relationships between knowledge and action in cross-scale governance. These relationships are, I suggest, a more prudent focus if adaptive governance is to move from theory into practice.

\section{LITERATURE}

\section{Coproduction}

"Coproduction" is discussed in two distinct but overlapping literatures. The first adopts coproduction as a critical analytical lens to view science-society interactions (Jasanoff 2004b). This analysis focuses on the coevolutionary relationships between our understanding of reality (the material), our knowledge of that reality (the cognitive), the context of knowledge production (the social), and how we choose to act in the world (the normative). These accounts explore how ideas gain cognitive, moral, and political standing and how knowledge is integrated into society (Jasanoff 2004a), to emphasize the power of knowledge and the critical normative choices shaping the interface between knowledge, social practices, and institutions (Miller 2004). Once knowledge is embedded within decision making, coproductive processes continue as institutions perpetuate a particular understanding of the natural world (Jasanoff 2004a). Coproduction highlights the cultural and scientific influences on governance and cautions against considering these influences in isolation.

Coproduction is also an aspirational goal of collaborative knowledge production. This emerged from growing recognition of the inadequacy of linear approaches to translating science into policy and practice (Lemos and Morehouse 2005, Armitage et al. 2011, Dilling and Lemos 2011). This coproductive model builds interactions among actors who produce and implement science and policy (Lemos and Morehouse 2005). These studies stress the importance of enabling policies and relationships built over time (Armitage et al. 2011); a commitment to interdisciplinarity; stakeholder participation and iterative collaboration (Lemos and Morehouse 2005); and the capacities, i.e., institutional, human, financial, and organizational, to use information (Dilling and Lemos 2011). Through socially embedded practices of knowledge production, coproduction is framed as a crucial link between knowledge and action (Cash et al. 2006).

Coproduction in both invocations is relevant to adaptive governance. Precursors to adaptive governance, adaptive management and ecosystem-based management, directed significant attention to scientific understandings of uncertainty and nonlinear system dynamics (Armitage et al. 2009). However, in the shift from adaptive "management" to "governance," the role of science in governance has remained largely unexamined. An overemphasis on improving scientific understandings of system resilience leaves the socio-political processes shaping adaptive governance largely unquestioned (Goldstein 2008, Cote and Nightingale 2011), and the focus on design principles and diagnostics provides little insight into the relationships underpinning collective action (Steins and Edwards 1999, Cleaver 2000). Responding to these critiques, coproduction as a critical lens illuminates contextually based power relations and normative aspirations underpinning scientific knowledge in adaptive governance, whereas coproduction as collaborative knowledge making highlights the mechanisms and relationships required to connect knowledge and action.

\section{Boundary and bridging organizations}

Concepts of "boundary work" illustrate how the boundaries between science, policy, and practice are shaped by communication and negotiation (Van Kerkhoff and Lebel 2006) to consider the processes, organizations, and functions that connect knowledge with action (Guston 1999, Cash et al. 2003). "Boundary organizations" occupy the space between science and policy to facilitate joint knowledge production through communication, mediation, and translation among actors in different arenas (Guston 2001, Carr and Wilkinson 2005, Cash et al. 2006). Boundary organizations provide accountability to actors on both sides of the boundary, while connecting and coordinating activities between actors (Cash et al. 2003). These studies highlight the importance of attending to disparities of power and knowledge among actors engaged in boundary work (Guston 1999). However, narrowly conceptualizing boundary organizations as existing between "science" and "policy" challenges theorizing this in-between space among other disparate communities (Sternlieb et al. 2013). "Bridging organizations" perform a similar role in connecting actors across scales however they are conceptualized within the context of governance networks (Olsson et al. 2007, Crona and Parker 2012). Bridging organizations can provide arenas for trust building, learning, collaboration, and conflict resolution (Hahn et al. 2006) and can be sites of knowledge coproduction (Berkes 2009). Bridging organizations are said to enhance individual and organizational capacity to support effective comanagement and cross-scale governance (Olsson et al. 2007, Berkes 2009).

\section{Adaptive capacity}

Adaptive capacity provides a conceptual basis to examine the ability of actors in collaborative governance to respond to uncertainty and change (Plummer and Armitage 2010). Studies of adaptive capacity focus on the social and physical preconditions to enable proactive or reactive adaptation, as well as the ability to mobilize these components in response to perceived or current stresses (Engle 2011). These "determinants" of adaptive capacity include technical options, availability and distribution of resources, structure of institutions and governance, human and social capital, knowledge generation and management, and risk perceptions (Yohe and Tol 2002). Adaptive capacity is context, scale, and policy specific, enabled or constrained by cross-scale socio-political and institutional factors (Adger and Vincent 2005). With increasing evidence of connections between individual and institutional adaptive capacity (Matthews and Sydneysmith 2010), focus on the institutional factors shaping adaptive capacity at local scales 
grows. These factors include knowledge, experience and expertise, networks, transparency, trust, commitment, leadership, legitimacy, accountability, collaboration, and flexibility (Hill and Engle 2013). Despite important insights, this literature predominantly focuses on how these factors enable or constrain the adaptive capacity of actors, rather than the capacity of the institutions to be "adaptive."

\section{Coproductive capacities}

A number of convergent insights emerge from these literatures, most notably, the multiple actors and knowledges shaping adaptive governance, adaptive capacity, and coproduction; the importance of connections between actors to support dialogue and learning; and the varied internal and external drivers affecting actors' ability to be adaptive. However, unanswered questions remain as to the institutional attributes and relational factors to connect actors through cross-scale governance (Plummer and Armitage 2010), as well as the capacity of these actors to connect knowledge with action. Considering these actors' internal characteristics, i.e., their knowledge resources, skills, or technical capacity, alone are insufficient, as broader structural, sociopolitical, and institutional factors come into play. Coproductive capacities must be understood within the broader socio-political arena of coproduction and adaptive governance.

The coproductive capacities endogenous to a governance network are my principal focus. Jasanoff's material, cognitive, social, and normative domains are used to distinguish capacities of a different nature, whereas I extend concepts from boundary work to focus on the capacities to connect knowledge with action in cross-scale governance (see Fig. 1).

Fig. 1. Coproductive capacities framework.

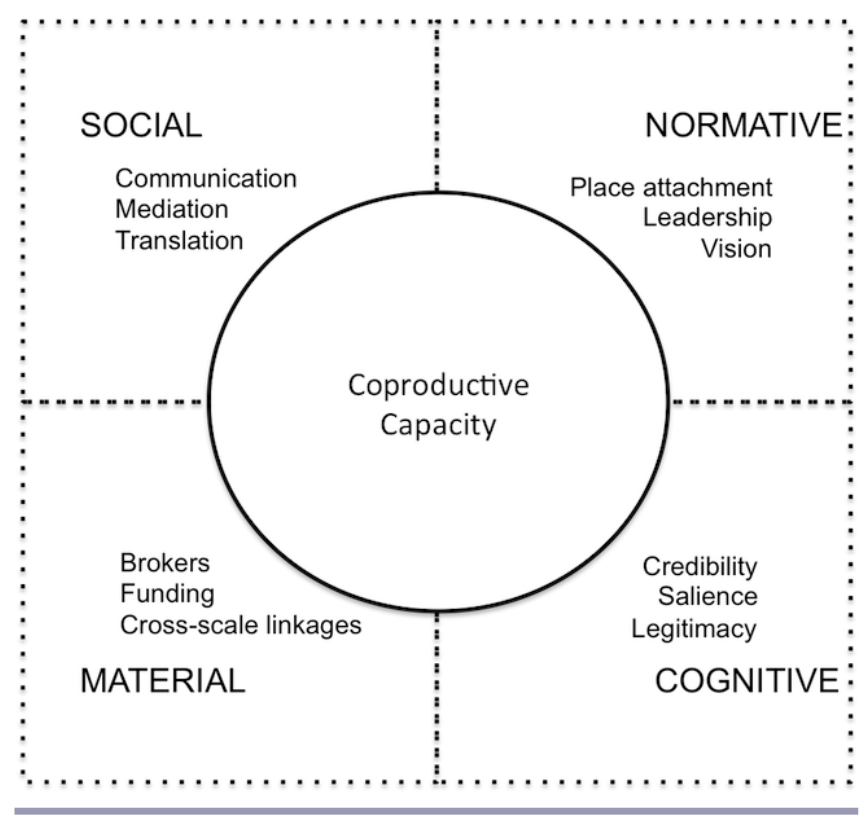

\section{Material}

The material concerns the tangible human resources, financial, and structural capacities to sustain relationships between actors at different scales. Adaptive governance (Folk et al. 2005) and links between knowledge and action (Reid et al. 2009) require secure, adequate, and flexible funding. Brokers and informal networking spaces provide conduits for sharing knowledge across scales and groups (Olsson et al. 2007, Pelling et al. 2008); however, this requires dedicated resources to train, support, incentivize (Dilling and Lemos 2011), and institutionalize (Lejano and Ingram 2009) these capacities in practice.

\section{Cognitive}

Cognitive capacities concern the processes of generating knowledge and turning that knowledge into action. These processes can build trust in collaborations while also generating legitimacy for local action (Hahn et al. 2006). Studies of boundary work illustrate the conflicting interpretations of reliable or usable knowledge, pointing to the importance of enhancing the credibility, salience, and legitimacy of scientific knowledge (Clark et al. 2010). Credibility concerns the scientific adequacy of technical evidence and arguments, salience refers to the relevance of knowledge to decision-makers' needs, and legitimacy in this context relates to perceptions of whether information is generated in fair and unbiased processes that respect actors' divergent beliefs and values (Cash et al. 2003).

\section{Social}

The social concerns the capacities to produce effective and equitable governance. Collaboration is commonly proposed to improve the use of knowledge in practice; however, boundary scholarship shows that collaboration alone is rarely sufficient (Cash et al. 2006). Effective boundary organizations perform three critical functions: communication, mediation, and translation (Cash et al. 2003). Iterative communication supports open dialogue, translation facilitates shared understanding of different terminology, and mediation supports transparent and legitimate negotiation of conflicting perspectives. The social also encompasses the capacity to engage with a broad spectrum of stakeholders though transparent and legitimate consultation processes.

\section{Normative}

Normative capacities concern the underlying values inspiring actors to work toward a common goal. The motivation to act is central to adaptive capacity and comanagement (Olsson et al. 2007). Leadership can provide inspiration and functional links to exchange information between groups (Olsson et al. 2007). A firm vision provides direction and, if paired with flexible governance, can enable actors to adopt different strategies to meet an overarching goal (Hahn et al. 2006, Wyborn 2013). Concern for a particular place, be it on a local or regional scale, can motivate action and negotiation of different management objectives (Williams 2002). Translocal-area-based initiatives embodying the adage "think global, act local" illustrate connections between place attachment and adaptive capacity (Devine-Wright 2013).

\section{METHODS}

This research examined two case studies (see Table 1), Yellowstone to Yukon (Y2Y) in the Rocky Mountains of the United States and Canada (Fig. 2) and Habitat $141^{\circ}$ in southeastern Australia (Fig. 3). Y2Y is widely regarded as a leading example of connectivity conservation (Locke 2010), whereas Habitat $141^{\circ}$ is a more recent initiative emerging with a contrasting approach to Y2Y. I draw on a larger study of the interplay between science, 
Table 1. Basic comparison of $\mathrm{Y} 2 \mathrm{Y}$ and Habitat $141^{\circ}$.

\begin{tabular}{|c|c|c|}
\hline & Y2Y & Habitat $141^{\circ}$ \\
\hline Year of establishment & 1993 & 2005 \\
\hline Size & 1.2 million $\mathrm{km}^{2} ; 3200 \mathrm{~km}$ long, $200-800 \mathrm{~km}$ wide & $18,000 \mathrm{~km}^{2} ; 700 \mathrm{~km}$ long, $200 \mathrm{~km}$ wide \\
\hline Jurisdictions & $\begin{array}{l}\text { USA: Montana, Idaho, Wyoming } \\
\text { Canada: British Columbia, Alberta, the Yukon } \\
\text { Territories } \\
\text { Tribal Lands of } 31 \text { Canadian First Nations and U.S. } \\
\text { Native American Tribes }\end{array}$ & Victoria, South Australia, New South Wales \\
\hline Major Players & Conservation activists, scientists, conservation NGOs & $\begin{array}{l}\text { Government agencies, conservation NGOs, } \\
\text { community stewardship groups }\end{array}$ \\
\hline Vision & $\begin{array}{l}\text { Combining science with stewardship, we seek to } \\
\text { ensure that the world-renowned wilderness, wildlife, } \\
\text { native plants, and natural processes of the } \\
\text { Yellowstone to Yukon region continue to function as } \\
\text { an interconnected web of life, capable of supporting } \\
\text { all of its natural and human communities, for now } \\
\text { and for future generations }\end{array}$ & $\begin{array}{l}\text { To work with communities to conserve, restore and } \\
\text { connect habitats for plants and wildlife on a landscape } \\
\text { scale from the outback to the ocean }\end{array}$ \\
\hline Governance structure & $\begin{array}{l}\text { Registered nonprofit with a split board on either side } \\
\text { of the U.S./Canadian border }\end{array}$ & $\begin{array}{l}\text { Alliance operating under a memorandum of } \\
\text { understanding }\end{array}$ \\
\hline Focus & $\begin{array}{l}\text { Large carnivore conservation, advocacy, wilderness } \\
\text { and protected area conservation, collaborative } \\
\text { conservation }\end{array}$ & $\begin{array}{l}\text { Natural resource management, ecological restoration, } \\
\text { collaborative conservation, economic development }\end{array}$ \\
\hline
\end{tabular}

Fig. 2. Yellowstone to Yukon, crossing the U.S./Canadian border in the northern Rocky Mountains.

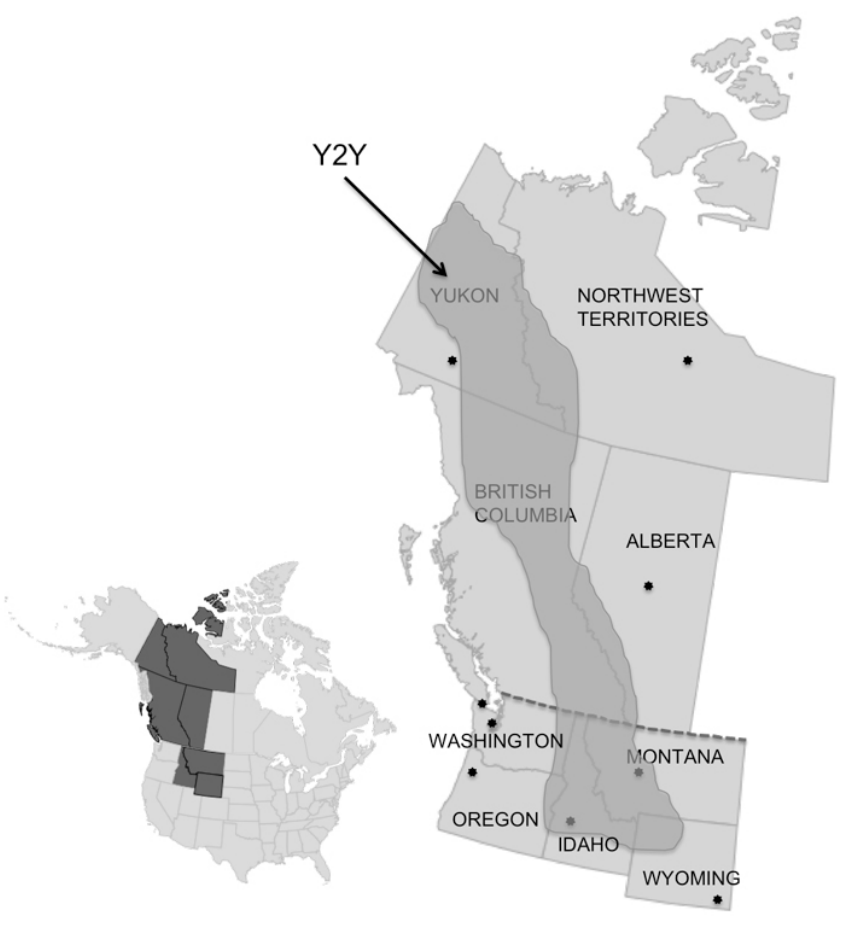

governance, and scale in connectivity conservation (Wyborn 2013). Connectivity conservation, and these cases, represents a novel attempt to adopt the ideas of adaptive governance in practice. I focus on the capacities that enabled the initiatives in these cases to connect knowledge with action in a cross-scale governance context.
Fig. 3. Habitat $141^{\circ}$, situated along the Victorian South Australian border in southeastern Australia.

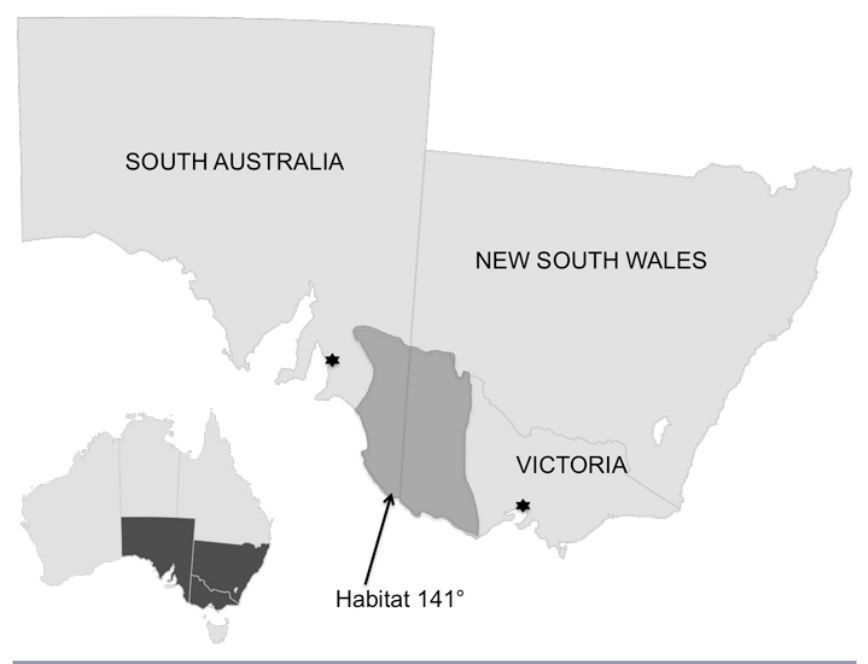

I used qualitative methods grounded in the adaptive theory approach (Layder 1998). Unlike grounded theory, which theorizes from empirical data (Strauss and Corbin 1998), a series of "orienting concepts" guides the negotiation of the theoretical and empirical in an adaptive, iterative process (Layder 1998). The orienting concepts evolved over the 4 years of this research, enabling theoretical and empirical insights to guide the research design. Empirically derived orienting concepts of values, science, and scale evolved to theoretical conceptualizations of coproduction, adaptive governance, and legitimacy. I conducted 21 semistructured interviews with past and present staff, partners, and board members of Y2Y, and 13 with representatives of organizations from the Habitat $141^{\circ}$ alliance. The interviews focused on connectivity governance, experiences of collaboration, 
the role of science in decision making, and the challenges of and strategies adopted to connect decision making across scales. Interviews were recorded, transcribed verbatim, and coded in NVIVO 9.2.

In a period of embedded research (Wickson 2006), I participated as an "active observer" in a Governance Working Group (GWG) charged with developing Habitat $141^{\circ}$ 's governance. Initially, I contributed to discussions while abstaining from voting in formal meetings. Overtime, I was invited to participate on similar terms to other participants. Embedded research creates deeper contextual understanding; however, it brings the researcher's subjectivity to the fore. This unavoidably shaped the process and analysis of this research because the GWG negotiations directed the adaptive research process. Moving beyond notions of objective research, this approach can build research validity because analysis begins during interaction with those shaping the phenomena under investigation (Flyvbjerg 2001, Demeritt and Dyer 2002, Wickson 2006). Participation in the GWG enabled practitioners involved with Habitat $141^{\circ}$ to critique theoretical and empirical insights. My relationship with the GWG did not prevent analysis of politics and challenges that marred the governance negotiations.

I used a constant comparative approach to explore variation across and within the cases (Boeiji 2010). NVIVO's matrix coding queries supported a multistaged comparative analysis of theoretical material, orienting concepts, and empirical data. Matrix displays cross two or more dimensions or variables to support comparative analysis and systematic exploration of data in visual displays that illuminate connections and relationships between core concepts (Miles and Huberman 1994). Through a bifocal lens of coproduction and adaptive governance, I analyzed what the different theoretical perspectives highlighted in the data. I did not make a comprehensive analysis of all factors pertaining to coproduction and adaptive governance; rather, I focused on how coproductive capacities enabled these initiatives to connect knowledge with action through cross-scale collaborative governance.

\section{FINDINGS}

Table 2 summarizes interview data pertaining to the coproductive capacities framework. I introduce each case context before discussing the coproductive capacities. These data reflect the different developmental stages of these initiatives: In Y2Y, analysis focuses on the relationships with regional partners and stakeholders, whereas Habitat $141^{\circ}$ focuses on the governance negotiations.

\section{YELLOWSTONE TO YUKON}

\section{Context}

Y2Y began in the early 1990s among conflicting visions for the future of the Rocky Mountains. Images of an Old West are tied to extractive industries, i.e., mining, logging, and agriculture; whereas the New West invokes ideas of wilderness and the protection of large tracts of land (Worster 1992). Y2Y emerged in this polarized landscape, promoting science-based advocacy to enhance carnivore conservation. Guided by the nascent science of conservation biology, Y2Y's conservation strategy had two pillars: science and activism (Levesque 2000). Interviewees reflected on how the diverse and inconsistent laws governing regional carnivore conservation (Keiter and Locke 1996) directed early focus on rigorous science, advocacy, regulation, and litigation to achieve the $\mathrm{Y} 2 \mathrm{Y}$ vision. Y2Y pioneered collaboration among environmental groups across the U.S./Canadian border, which previously had very little contact. However, their vision of wilderness and protected areas sparked significant backlash from communities dependent on extractive industries (Locke 2010), which held a long-standing suspicion of government and environmentalists and feared a loss of property rights (Chester 2006). Y2Y began as a collaboration of organizations; however, it now operates as an independent nonprofit, the Yellowstone to Yukon Conservation Initiative (Y2YCI), which collaborates with more than 200 "partners" working at local scales across the region.

\section{Coproductive capacities}

\section{Material}

Y2Y attracts significant philanthropic donations to support its vision. In the early years, this was largely directed to scientific research, including a US\$1.5 million Science Grants Program to inform its conservation strategy. $\mathrm{Y} 2 \mathrm{Y}$ now runs a minigrants program to support conservation groups to implement its vision, distributing US\$570,000 since 1998. However, interviewees representing Y2Y's partners and former staff reported challenges with the power dynamic created by Y2Y's financial clout.

Although not formally named as such, Y2Y's coordinator acts as a broker throughout the region. Interviewees recognized that one broker is insufficient in such a large region; however, board members reported that staff increases surpassed the capacity of Y2Y. As a small organization, Y2Y shifts focus to regions with the greatest current pressures; however, this undermines its capacity to build strong local connections. Y2Y's work in 12 priority areas supports collaboration among regional partners; however, there are no structural linkages between decision making in the priority areas, nor between the partners and the Y2YCI board or executive director.

\section{Cognitive}

According to interviewees, the first decade of Y2Y's work assumed that credible peer-reviewed science would give its vision standing in policy or legal circles. Many interviewees now reflected that this linear model of getting the "facts right first" largely failed to motivate behavioral change. Although Y2Y's focus on science played directly into resentment of environmentalists, interviewees believed that questions of Y2Y's legitimacy concerned the initiative and its vision rather than the science itself. Much of the scientific research addressed questions relevant to the region as a whole, and some interviewees questioned the salience of coarsescale science to local-scale conservation.

\section{Social}

Communication, mediation, and translation in $\mathrm{Y} 2 \mathrm{Y}$ involves two somewhat distinct arenas: between $\mathrm{Y} 2 \mathrm{Y}$ and its partners, and with the broader community. Some partners spoke of being overly directed by Y2Y; however, others reported healthy relationships with the organization. The Y2Y Listserv provides critical connections between conservation organizations working across the U.S./Canadian border.

Beyond public messaging and efforts to communicate $\mathrm{Y} 2 \mathrm{Y}$ science, Y2Y chose not to engage with government, landholders, or extractive industries. Interviewees working directly with these communities believed this had a lasting impact on the legitimacy 
Table 2. Summary of interview data in relation to coproductive capacities framework.

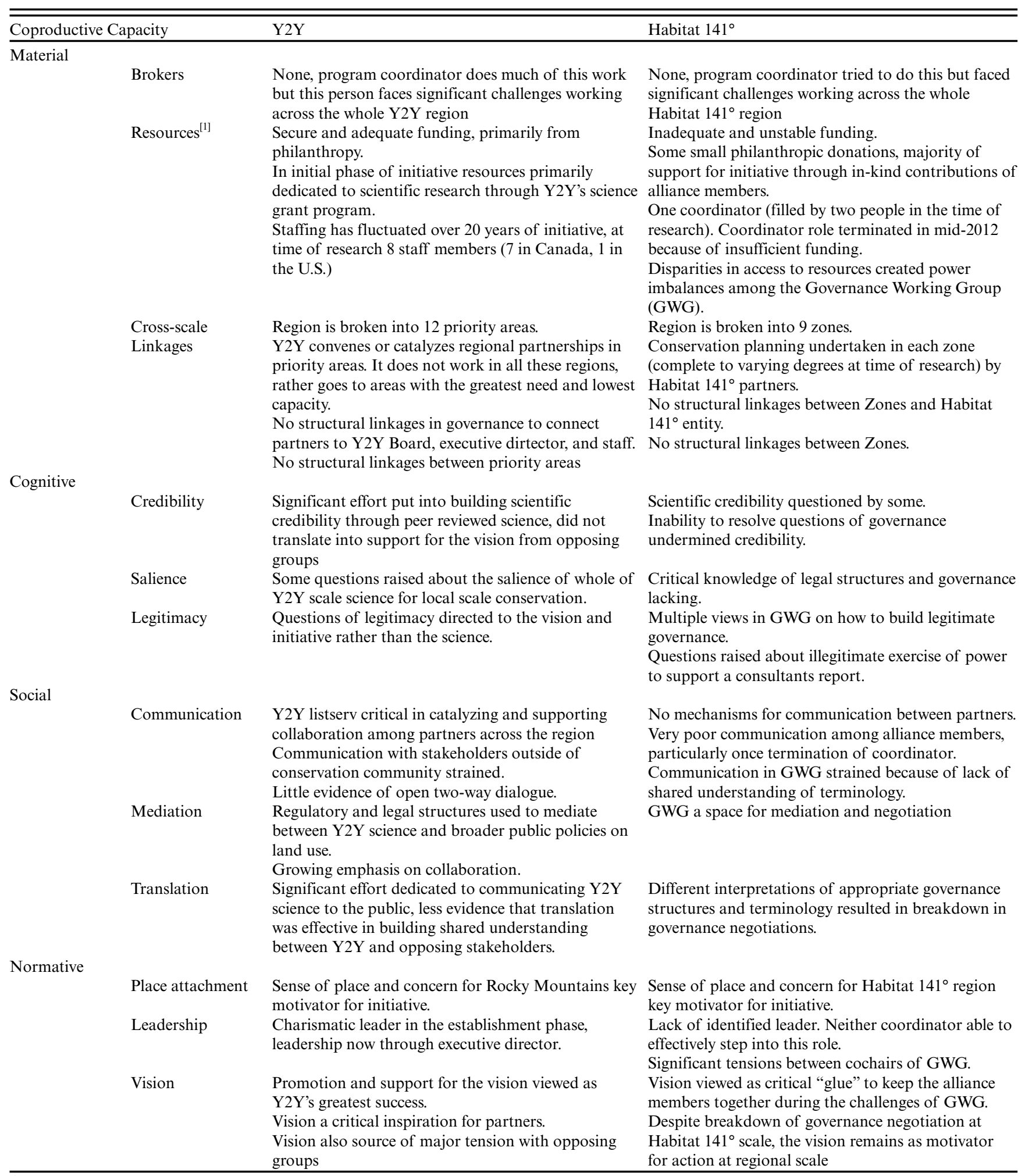

${ }^{[1]}$ The importance of resources in shaping coproductive capacity emerged through the research process, thus quantitative data on total resources for each entity was not gathered. Rather the qualitative data gives an overall picture of the security and adequacy of funding and where resources where directed. 
of the organization and its vision. Others maintained that the backlash misrepresented the $\mathrm{Y} 2 \mathrm{Y}$ vision, and although they acknowledged challenges in those communities, stood by the decision to only collaborate with conservation groups.

\section{Normative}

The charismatic leadership of a lawyer from Canada and an American conservation biologist guided and promoted Y2Y's early years, generating both support and antagonism toward the vision. This vision, which appeals to the imagery of the Rocky Mountains while promoting the idea of science-led stewardship, is widely heralded as the initiative's greatest success. All interviewees reported being inspired by the vision and saw the value of harnessing regional attachments to place. However, the vision also created significant tension with opposition groups.

\section{HABITAT $141^{\circ}$}

\section{Context}

Since the 1980s, conservation groups, agricultural associations, and the Australian federal government have supported voluntary collaborations to undertake local-scale conservation (Curtis and Lockwood 2000). Extending this tradition, Habitat $141^{\circ}$ promises to address pressures shared by both farmers and conservationists. The scientific basis of connectivity conservation in the Australian landscape presents ongoing academic debate (see Hodgson et al. 2009, 2011, Possingham 2009, Doerr et al. 2011). Despite this, in 2011-12 the federal government developed a major policy initiative, the National Wildlife Corridor Plan, to support connectivity conservation. At the time of research, the plan had little direct bearing on Habitat $141^{\circ}$; however, its presence legitimized Habitat $141^{\circ}$ 's efforts. A broader policy context created competition for finite resources (Robins and Kanowski 2011), which interviewees believed affected the governance negotiations.

Habitat $141^{\circ}$ emerged in 2005 as an alliance of 14 organizations from across public, private, and civil society to support collaborative natural resource management (NRM) and ecological restoration. During this research, major conservation nongovernmental organizations (NGOs) and government agencies in the alliance focused on developing governance arrangements to connect local- and regional-scale decision making. These arrangements intended to create a Habitat $141^{\circ}$ "entity" to support a network of partners. Partnership was to be open to any organization that signed on to the Habitat $141^{\circ}$ vision. The dominance of large organizations in the governance negotiations alienated smaller organizations previously involved in the initiative. According to some interviewees, this undermined the capacity of the alliance to connect with local-scale actors. The negotiations disbanded after different perspectives on how to structure the governance arrangements could not be reconciled.

\section{Coproductive capacities}

\section{Material}

Habitat $141^{\circ}$ began with aspirations to attract substantial resources, making the governance negotiations a site of power and politics. Interviewees discussed how disunities emerged after an initial bid for government funding failed. Beyond in-kind contributions and small philanthropic grants, Habitat $141^{\circ}$ was unable to attract sufficient resources. Interviewees attributed challenges in the GWG negotiations to the absence of funding and significant imbalances in financial capacity. Many reflected on the misuse of financial power to leverage outcomes, including the termination of the coordinator with very little consultation during a financial crisis in the leading NGO.

Habitat $141^{\circ}$ is broken into nine zones, where partners conduct regional-scale conservation planning. A Habitat $141^{\circ}$ entity was to operate across the whole region; however, the GWG was unable to agree on the structure of this entity and what its powers would be. In a constrained financial space, brokers to connect the zones to one another and to the entity were beyond the capacity of Habitat $141^{\circ}$.

\section{Cognitive}

Despite diverse expertise among the GWG, Habitat $141^{\circ}$ did not effectively mobilize cognitive resources to support action. Prior to the GWG formation, one of the partners funded a consultant to develop governance options without consulting the broader alliance on the terms of reference. Many interviewees viewed this as an illegitimate use of financial power, particularly when the narrow terms of reference and recommendations in the report largely supported the position of the partner who funded it. Habitat $141^{\circ}$ did not have funding to support scientific research or legal advice on governance structures. The lack of salient governance expertise presented the biggest challenge because interviewees reported that protracted governance negotiations undermined Habitat $141^{\circ}$ 's credibility among local-scale actors.

\section{Social}

The GWG built trust among different perspectives; however, interviewees reflected on substantial miscommunications around key ideas. The GWG spent significant time debating legal structures for governance, which many interviewees subsequently felt detracted from discussing the distribution of power between the entity, the zones, and the partners. Despite eight months of negotiations, the interviews revealed fundamentally different interpretations of terminology and preferences for governance arrangements. Translation processes to generate a shared understanding of terminology were largely absent, and mediation between differing perspectives was ineffectual. The GWG consulted with a broad suite of stakeholders on proposed governance arrangements; however, an interim executive committee that took over from the GWG failed to communicate major changes in proposed governance to these stakeholders.

\section{Normative}

The Habitat $141^{\circ}$ vision received significant grassroots and government support. Interviewees framed the vision as a foundational "glue" to work through the challenging governance negotiations. The vision's commitment to work with local communities was critical and often invoked in discussions about the exercise of power by larger organizations in the alliance. Interviewees reflected that agreeing to a vision, although critical, was much easier than putting the vision into action.

Leadership was, however, a major hurdle. Habitat $141^{\circ}$ had many potential leaders but no one person filling the role. Interviewees reflected on major tensions between the GWG cochairs, whereas the coordinators discussed how the powerful organizations constrained their leadership potential. In the absence of effective collaborative leadership, individual leadership was often viewed as an illegitimate exercise of power. 


\section{DISCUSSION}

In both cases, normative capacities associated with the vision and attachment to place were effectively mobilized. Adaptive comanagement literature emphasizes the importance of a vision (Hahn et al. 2006, Olsson et al. 2007); however, this is less prominent in discussions of coproduction, adaptive capacity, and boundary/bridging organizations. Participation in both cases was voluntary, making belief in the vision an important capacity to act. Relying on normative capacities also brings challenges. For Y2Y, the vision exacerbated long-standing tensions, and in Habitat $141^{\circ}$, a shared vision concealed fundamentally different perspectives. These cases demonstrate the importance of considering normative capacities and how they constrain or enable adaptive governance.

Despite different approaches to turn the vision into action, an inspiring vision is not enough. Habitat $141^{\circ}$ attempted and struggled to develop inclusive governance, whereas Y2Y focused on building legitimacy through scientific credibility. By directing attention to the structures of governance or the rigors of science, both neglected to support the material capacities to connect actors across scales. Although interviewees in both cases saw value in cross-scale brokers, they lacked the financial capacity to support these positions. The absence of brokers or structural linkages between different arenas of governance constrained their material coproductive capacity. Coproductive capacity requires networks and relationships to connect actors from different domains. Y2Y's Science Grant Program is exemplary. This funding stream specifically built capacity among young scientists while supporting relationships between scientists and activists. Funding mechanisms shape implementation: Without funding, these encounters are very difficult to sustain.

More funding is not a panacea, as evidenced by the financial distortion of power in both cases. Power pervades all domains of coproductive capacity, from questions of where finances are directed to mediating different visions for the future. Matthews and Sydneysmith (2010) show how the adaptive capacity of groups or individuals relates to their power, legitimacy, or authority to act within or outside of institutional structures, whereas Jasanoff (2004a) questions the cognitive authority of science in decision making. These are critical questions for adaptive governance scholarship (Fabricius et al. 2007). Access to knowledge and the resources to bring that knowledge into action reinforce the power of those with such capacity, bringing to the fore the importance of legitimate governance processes. That power shapes collaborative governance is not a particularly novel insight. However, understanding where power intersects with the coproductive capacities outlined provides an analytical entrée into how power manifests at the intersection of knowledge and action.

The broader socio-political context of these initiatives shaped the coproductive capacities. During intense resource conflict in the Northern Rockies, the regulatory and legal structures directing land-use planning were viewed as a more productive mobilization of social capacities than engaging with groups seen as "the enemy." Since realizing the absence of linear relationships between credible science and policy change, Y2Y now directs more funding to implementation than science. In Habitat $141^{\circ}$ 's case, its challenges in effectively mobilizing material and social capacities can, in part, be attributed to competition between the partners created by changes in federal government policy. These changes played a large part in the financial crisis of the leading NGO. Fluctuating funding structures have had a detrimental effect on capacity and relationship building in Australian NRM (Lovett et al. 2008). Without adequate material capacities, potential capacities in other domains are unlikely to be realized.

In the absence of brokers to connect actors in the landscape, other mechanisms are needed to support cross-scale governance. Semiregular professional forums can provide spaces for actors to build informal networks (Pelling et al. 2008, Bates et al. 2012). Informal networks direct attention to building relationships and sharing ideas without requiring agreement on the structural composition of governance. Many interviewees from Habitat $141^{\circ}$ reflected on this very tension because they came to realize that "having the perfect governance structure" could not build productive relationships.

\section{CONCLUSION}

The absence of direct relationships between knowledge and action constrained both initiatives' capacity to govern adaptively in a cross-scale context. Whether it is the inability of Y2Y's science to legitimize its vision for a sustainable future or the complex governance of Habitat $141^{\circ}$ that lost touch with those it was seeking to empower, these cases show that science and governance alone will not build coproductive capacity. The structures of governance and the rigors of science need to be brought into practice through the interactions and relationships between people.

Returning to the capacities that enabled these initiatives to connect knowledge with action in cross-scale governance, these cases highlight the interplay between domains of coproductive capacity. This is most apparent as it pertains to the material capacities to support actors to engage across scales, without which mobilizing other capacities is difficult. The initiatives were both empowered by their normative capacities; however, in Y2Y's case, its normative commitments influenced how it mobilized social and cognitive capacities. For Habitat $141^{\circ}$, it concealed fundamentally different perspectives.

The coproductive capacities framework supported a systematic inquiry into how different capacities challenged the ability of these initiatives to connect knowledge with action. This framework can provide guidance of the capacity domains for practitioners, policy makers, and scientists to consider. However, identifying the importance of particular capacities in their absence is not enough to assume that, if present, these capacities will be sufficient. Capacity is demonstrated when actors are enabled to undertake action. Consequently, different insights will emerge from cases in which coproductive capacities are effectively harnessed to connect knowledge with action.

Supporting relationships that connect knowledge with action should be a central task of adaptive governance. The structural mechanisms of adaptive governance have received significant attention; yet coproductive capacity is built through relationships, not structures. Rather than focus on design principles and diagnostics, a more useful approach to adaptive governance would build coproductive capacity to negotiate these relationships in context. 
Responses to this article can be read online at: http://www.ecologyandsociety.org/issues/responses. php/6510

\section{Acknowledgments:}

This research was funded by a Land and Water Australia Ph.D. scholarship and a CSIRO Climate Adaptation Flagship top-up scholarship. Thank you to the participants of Habitat $141^{\circ}$ and $Y 2 Y$ for the time and support they gave to this study. The original manuscript was substantially improved by the detailed guidance of three anonymous reviewers, to whom I am extremely grateful. Thanks also to Lorrae van Kerkhoff, Deborah Cleland, and Louis Lebel for comments on drafts of the manuscript.

\section{LITERATURE CITED}

Adger, W. N., and K. Vincent. 2005. Uncertainty in adaptive capacity. Comptes Rendus Geoscience 337(4):399-410.

Armitage, D., F. Berkes, A. Dale, E. Kocho-Schellenberg, and E. Patton, 2011. Co-management and the co-production of knowledge: learning to adapt in Canada's Arctic. Global Environmental Change 21(3):995-1004. http://dx.doi.org/10.1016/ j.gloenvcha.2011.04.006

Armitage, D. R., R. Plummer, F. Berkes, R. I. Arthur, A. T. Charles, I. J. Davidson-Hunt, A. P. Diduck, N. C. Doubleday, D. S. Johnson, M. Marschke, P. McConney, E. W. Pinkerton, and E. K. Wollenberget. 2009. Adaptive co-management for socialecological complexity. Frontiers in Ecology and the Environment 7(2):95-102. http://dx.doi.org/10.1890/070089

Bates, L. E., M. Green, R. Leonard, and I. Walker, 2012. The influence of multilevel governance systems on the development and implementation of climate adaptation practices within organizations in Australia. Paper presented at the IVM Governance of Adaptation Symposium (Amsterdam, 22-23 March 2012). [online] URL: http://www.adaptgov.com/wp-content/ uploads/2012/03/Bates-multilevel-governance-systems-A77-Taction. pdf

Berkes, F. 2009. Evolution of co-management: role of knowledge generation, bridging organizations and social learning. Journal of Environmental Management 90(5):1692-1702. http://dx.doi. org/10.1016/j.jenvman.2008.12.001

Boeiji, H. 2010. Analysis in qualitative research. Sage, London, UK.

Carr, A., and R. Wilkinson. 2005. Beyond participation: boundary organizations as a new space for farmers and scientists to interact. Society \& Natural Resources 18:255-265. http://dx.doi. org/10.1080/08941920590908123

Cash, D. W., J. C. Borck, and A. G. Patt. 2006. Countering the loading-dock approach to linking science and decision making: comparative analysis of El Niño/Southern Oscillation (ENSO) forecasting systems. Science, Technology, \& Human Values 31 (4):465-494. http://dx.doi.org/10.1177/0162243906287547

Cash, D. W., W. C. Clark, F. Alcock, N. M. Dickson, N. Eckley, D. H. Guston, J. Jäger, and R. B. Mitchell. 2003. Knowledge systems for sustainable development. Proceedings of the National
Academy of Sciences of the United States of America 100 (14):8086-8091. http://dx.doi.org/10.1073/pnas.1231332100

Chester, C. 2006. Conservation across borders: biodiversity in an interdependent world. Island, Washington, D.C., USA.

Clark, W. C., T. P. Tomich, M. Van Noordwijk, N. Dickson, D. Catacutan, D. Guston, and E. McNie. 2010. Toward a general theory of boundary work: insights from the CGIAR's natural resource management programs. Working Paper No. 1999, Centre for International Development at Harvard University, Cambridge, Massachusetts, USA.

Cleaver, F. 2000. Moral ecological rationality, institutions and the management of common property resources. Development and Change 31:361-383. http://dx.doi.org/10.1111/1467-7660.00158

Cote, M., and A. J. Nightingale. 2011. Resilience thinking meets social theory: situating social change in socio-ecological systems (SES) research. Progress in Human Geography 36(4):475-489. http://dx.doi.org/10.1177/0309132511425708

Crona, B. I., and J. N. Parker. 2012. Learning in support of governance: theories, methods, and a framework to assess how bridging organizations contribute to adaptive resource governance. Ecology and Society 17(1): 32. http://dx.doi. org/10.5751/ES-04534-170132

Curtis, A., and M. Lockwood. 2000. Landcare and catchment management in Australia: lessons for state-sponsored community participation. Society \& Natural Resources 13(1):61-73. http://dx. doi.org/10.1080/089419200279243

Demeritt, D., and S. Dyer. 2002. Dialogue, metaphors of dialogue and understandings of geography. Area 34(3):229-241. http://dx. doi.org/10.1111/1475-4762.00077

Devine-Wright, P. 2013. Think global, act local? The relevance of place attachments and place identities in a climate changed world. Global Environmental Change 23(1):61-69. http://dx.doi. org/10.1016/j.gloenvcha.2012.08.003

Dilling, L., and M. C. Lemos. 2011. Creating usable science: opportunities and constraints for climate knowledge use and their implications for science policy. Global Environmental Change 21 (2):680-689. http://dx.doi.org/10.1016/j.gloenvcha.2010.11.006

Doerr, V. A. J., T. Barrett, and E. D. Doerr. 2011. Connectivity, dispersal behaviour and conservation under climate change: a response to Hodgson et al. Journal of Applied Ecology 48 (1):143-147. http://dx.doi.org/10.1111/j.1365-2664.2010.01899.x

Engle, N. L. 2011. Adaptive capacity and its assessment. Global Environmental Change 21(2):647-656. http://dx.doi.org/10.1016/ j.gloenvcha.2011.01.019

Fabricius, C., C. Folke, G. Cundill, and L. Schultz. 2007. Powerless spectators, coping actors, and adaptive co-managers: a synthesis of the role of communities in ecosystem management. Ecology and Society 12(1): 29. [online] URL: http://www.ecologyandsociety. org/vol12/iss1/art29/

Flyvbjerg, B. 2001. Making social science matter: why social inquiry fails and how it can succeed again. Cambridge University Press, Cambridge, UK. http://dx.doi.org/10.1017/CBO9780511810503

Folke, C., T. Hahn, P. Olsson, and J. Norberg. 2005. Adaptive governance of social-ecological systems. Annual Review of 
Environment and Resources 30(1):441-473. http://dx.doi. org/10.1146/annurev.energy.30.050504.144511

Goldstein, B. E. 2008. Skunkworks in the embers of the cedar fire: enhancing resilience in the aftermath of disaster. Human Ecology 36(1):15-28. http://dx.doi.org/10.1007/s10745-007-9133-6

Guston, D. H. 1999. Stabilizing the boundary between US politics and science: the role of the Office of Technology Transfer as a boundary organization. Social Studies of Science 29:87-111. http://dx.doi.org/10.1177/030631299029001004

Guston, D. H. 2001 Boundary organizations in environmental policy and science: an introduction. Science, Technology, \& Human Values 26:399-408. http://dx.doi.org/10.1177/016224390102600401

Hahn, T., P. Olsson, C. Folke, and K. Johansson. 2006. Trustbuilding, knowledge generation and organizational innovations: the role of a bridging organization for adaptive comanagement of a wetland landscape around Kristianstad, Sweden. Human Ecology 34(4):573-592. http://dx.doi.org/10.1007/s10745-006-9035$\underline{\mathrm{Z}}$

Hill, M., and N. L. Engle, 2013. Adaptive capacity: tensions across scales. Environmental Policy and Governance 23(3):177-192. http:// dx.doi.org/10.1002/eet.1610

Hodgson, J. A., A. Moilanen, B. A. Wintle, and C. D. Thomas. 2011. Habitat area, quality and connectivity: striking the balance for efficient conservation. Journal of Applied Ecology 48 (1):148-152. http://dx.doi.org/10.1111/j.1365-2664.2010.01919.x

Hodgson, J. A., C. D. Thomas, B. A. Wintle, and A. Moilanen, 2009. Climate change, connectivity and conservation decision making: back to basics. Journal of Applied Ecology 46(5):964-969. http://dx.doi.org/10.1111/j.1365-2664.2009.01695.x

Jasanoff, S. 2004a. Ordering knowledge, ordering society. Pages 13-45 in S. Jasanoff, editor. States of knowledge: the co-production of science and the social order. Routledge, New York, New York, USA.

Jasanoff, S., editor. 2004b. States of knowledge: the co-production of science and the social order. Routledge, New York, New York, USA. http://dx.doi.org/10.4324/9780203413845

Keiter, R. B., and H. Locke. 1996. Law and large carnivore conservation in the Rocky Mountains of the U.S. and Canada. Conservation Biology 10(4):1003-1012. http://dx.doi.org/10.1046/ j.1523-1739.1996.10041003.x

Layder, D. 1998. Sociological practice: linking theory and social research. Sage, London, UK.

Lebel, L., J. M. Anderies, B. Campbell, C. Folke, S. HatfieldDodds, T. P. Hughes, and J. Wilson. 2006. Governance and the capacity to manage resilience in regional social-ecological systems. Ecology and Society 11(1): 19. [online] URL: http://www. ecologyandsociety.org/vol11/iss1/art19/

Lejano, R. P., and H. Ingram. 2009. Collaborative networks and new ways of knowing. Environmental Science \& Policy 12 (6):653-662. http://dx.doi.org/10.1016/j.envsci.2008.09.005

Lemos, M. C., and A. Agrawal. 2006. Environmental governance. Annual Review of Environment and Resources 31(1):297-325. http://dx.doi.org/10.1146/annurev.energy.31.042605.135621
Lemos, M. C., and B. J. Morehouse. 2005. The co-production of science and policy in integrated climate assessments. Global Environmental Change 15(1):57-68. http://dx.doi.org/10.1016/j. gloenvcha.2004.09.004

Levesque, S. 2000. From Yellowstone to Yukon: combining science and advocacy to shape public opinion and policy. Dissertation, University of California, Irvine, California, USA.

Locke, H. 2010. Yellowstone 2 Yukon. Pages 161-181 in G. Worboys, W. Francis, and M. Lockwood, editors. Connectivity conservation management: a global guide. Earthscan, London, UK.

Lockwood, M. 2010. Scoping the territory: considerations for connectivity conservation managers. Pages 34-51 in G. Worboys, W. Francis, and M. Lockwood, editors. Connectivity conservation management: a global guide. Earthscan, London, UK.

Lovett, S., J. Lambert, J. Williams, and P. Price. 2008. Restoring landscapes with confidence - an evaluation of the science, the methods and their on-ground application. Final Report, Land and Water Australia, Canberra, Australian Capital Territory, Australia.

Matthews, R., and R. Sydneysmith. 2010. Adaptive capacity as a dynamic institutional process: conceptual perspectives and their application. Pages 223-242 in D. Armitage and R. Plummer, editors. Adaptive capacity and environmental governance. Springer Series on Environmental Management. Springer-Verlag, Berlin, Germany. http://dx.doi.org/10.1007/978-3-642-12194-4 11

Miles, M., and A. Huberman. 1994. Qualitative data analysis: an expanded source book. Sage, Thousand Oaks, California, USA.

Miller, C. 2004. Climate science and the making of a global political order. Pages 46-55 in S. Jasanoff, editor. States of knowledge: the co-production of science and the social order. Routledge, New York, New York, USA.

Olsson, P., C. Folke, V. Galaz, T. Hahn, and L. Schultz. 2007. Enhancing the fit through adaptive co-management: creating and maintaining bridging functions for matching scales in the Kristianstads Vattenrike Biosphere Reserve, Sweden. Ecology and Society 12(1): 28. [online] URL: http://www.ecologyandsociety. org/vol12/iss1/art28/

Pelling, M., C. High, J. Dearing, and D. Smith, 2008. Shadow spaces for social learning: a relational understanding of adaptive capacity to climate change within organisations. Environment and Planning A 40(4):867-884. http://dx.doi.org/10.1068/a39148

Plummer, R., and D. Armitage. 2010. Integrating perspectives on adaptive capacity and environmental governance. Pages 1-19 in D. Armitage and R. Plummer, editors. Adaptive capacity and environmental governance. Springer Series on Environmental Management. Springer-Verlag, Berlin, Germany. http://dx.doi. org/10.1007/978-3-642-12194-4 1

Possingham, H. 2009. Big thinking for a big country: continentalscale connections: is bigger better? And if so, where do you put them? Decision Point 26(March):10-11. [online] URL: http:// www.aeda.edu.au/docs/Newsletters/DPoint 26.pdf

Reid, R. S., D. Nkedianye, M. Y. Said, D. Kaelo, M. Neselle, O. Makui, L. Onetu, S. Kiruswa, N. Ole Kamuaro, P. Kristjanson, 
J. Ogutu, S. B. BurnSilver, M. J. Goldman, R. B. Boone, K. A. Galvin, N. M. Dickson, and W. C. Clark. 2009. Evolution of models to support community and policy action with science: balancing pastoral livelihoods and wildlife conservation in savannas of East Africa. Proceedings of the National Academy of Sciences of the United States of America. Published online before print 3 November 2009. http://dx.doi.org/10.1073/pnas.0900313106

Robins, L., and P. Kanowski, 2011. 'Crying for our country': eight ways in which 'Caring for our Country' has undermined Australia's regional model for natural resource management. Australasian Journal of Environmental Management 18(2):88-108. http://dx.doi.org/10.1080/14486563.2011.566158

Steins, N. A., and V. E. Edwards. 1999. Collective action in common-pool resource management: the contribution of a social constructivist perspective to existing theory. Society \& Natural Resources 12(6):539-557. http://dx.doi.org/10.1080/089419299279434

Sternlieb, F., R. P. Bixler, H. Huber-Stearns, and C. Huayhuaca. 2013. A question of fit: reflections on boundaries, organizations and social-ecological systems. Journal of Environmental Management 130:117-125. http://dx.doi.org/10.1016/j. jenvman.2013.08.053

Strauss, A., and Corbin, J. 1998. Basics of qualitative research: techniques and procedures for developing grounded theory. Sage, London, UK.

Van Kerkhoff, L., and L. Lebel. 2006. Linking knowledge and action for sustainable development. Annual Review of Environment and Resources 31:445-477. http://dx.doi.org/10.1146/ annurev.energy.31.102405.170850

Van Kerkhoff, L. E., and L. Lebel. 2015. Coproductive capacities: rethinking science-governance relations in a diverse world. Ecology and Society 20(1): 14. http://dx.doi.org/10.5751/ ES-07188-200114

Virji, H., J. Padgham, and C. Seipt. 2012. Capacity building to support knowledge systems for resilient developmentapproaches, actions, and needs. Current Opinion in Environmental Sustainability 4(1):115-121. http://dx.doi.org/10.1016/j.cosust.2012.01.005

Walker, B., and D. Salt. 2006. Resilience thinking: sustaining ecosystems and people in a changing world. Island, Washington, D.C., USA.

Wickson, F., A. L. Carew, and A. W. Russell. 2006. Transdisciplinary research: characteristics, quandaries and quality. Futures 38(9):1046-1059. http://dx.doi.org/10.1016/j. futures.2006.02.011

Williams, D. R., editor. 2002. Post-utilitarian forestry: what's place got to do with it? Pages 114-123 in Proceedings of the Human Dimensions of Natural Resources in the West Conference (Alta, Wyoming, 18-21 October). Human Dimensions Unit, College of Natural Resources, Colorado State University, Fort Collins, Colorado, USA.

Worboys, G., W. Francis, and M. Lockwood, editors. 2010. Connectivity conservation management: a global guide. Earthscan, London, UK.
Worster, D. 1992. Under western skies: nature and history in the American West. Oxford University Press, New York, New York, USA.

Wyborn, C. 2011. Landscape scale ecological connectivity: Australian survey and rehearsals. Pacific Conservation Biology 17 (2):121-130.

Wyborn, C. 2013. Adaptive governance and connectivity conservation: exploring the interplay between science, governance and scale. Dissertation, Australian National University, Canberra, Australian Capital Territory, Australia.

Yohe, G., and R. S. J. Tol. 2002. Indicators for social and economic coping capacity-moving toward a working definition of adaptive capacity. Global Environmental Change 12(1):25-40. http://dx.doi.org/10.1016/S0959-3780(01)00026-7 